\title{
Changing purchasing habits through non-monetary point of sale strategies: the case of Australian oysters
}

\author{
Meredith Lawley $^{\mathrm{a} *}$, Dawn Birch ${ }^{\mathrm{b}}$ and Lucy Johnson ${ }^{\mathrm{c}}$ \\ ${ }^{\text {a }}$ Professor, School of Business, University of the Sunshine Coast, Sippy Downs, Australia \\ ${ }^{\mathrm{b}}$ Dr, Department of Marketing, Faculty of Management, Bournemouth University, Executive Business Centre, \\ 89 Holdenhurst Road, Bournemouth, United Kingdom, BH23 2EL \\ ${ }^{\text {c }}$ School of Business, University of the Sunshine Coast, Sippy Downs, Australia
}

\begin{abstract}
In Australia, oysters are perceived as luxury products or are reserved for special occasions, making their consumption infrequent. Point of sale (POS) strategies can encourage consumers to increase purchase frequency. This paper reports the results of a field trial conducted for the Australian oyster industry to increase oyster purchase frequency. Five non-monetary POS strategies were trialled over 16 weeks in seven specialty seafood stores. While issues with store POS strategy compliance made evaluation difficult, sales increased by 15-20\%; the most effective strategy was in-store sampling. Management and staff commitment to the POS campaign positively impacted results.
\end{abstract}

Keywords: Point of sale (POS), seafood, consumer behaviour, retailing

\section{Introduction}

Food consumption patterns are highly habituated (Honkanen et al., 2005; Verbeke \& Vackier, 2005) with consumers tending to buy the same foods from the same places for the same consumption occasions. This makes it difficult for food marketers of new and unfamiliar products to break into the consumption cycle or increase the purchase frequency of products associated with limited consumption occasions (Birch \& Lawley, 2014). For example, in Australia, oysters (despite being a popular seafood product) are bought and consumed infrequently by many oyster lovers. The challenge for the oyster industry is to encourage oyster eaters to purchase oysters more frequently and consider a broader range of consumption occasions (Liu, et al., 2006). Barriers to greater oyster consumption include: (i) the perception that oysters are a luxury food to be eaten only on special

\footnotetext{
${ }^{\mathrm{a} *}$ Corresponding author. Email addresses: mlawley1@usc.edu.au (M. Lawley), dbirch@bournemouth.ac.uk (D. Birch), lfitzger@usc.edu.au (L. Johnson)
} 
occasions; (ii) concerns about freshness and safety; and (iii) a lack of knowledge of sourcing, storing and serving oysters (Danenburg \& Mueller, 2011).

Point of sale (POS) strategies can be used to overcome these barriers and increase consumption (Point of Purchase Advertising International, 2012). Such strategies have influenced behavioural change of consumers and interrupt routine behaviour and thought patterns at the POS (Ogawa et al., 2011; Nikolova \& Inman, 2015).

While POS strategies have traditionally been designed to expedite the selling process and maximise sales volume (Belch \& Belch, 2007), longer term goals include building brand knowledge and improving brand image (Glanz \& Yaroch, 2004). POS strategies have emerged as an area of research interest in the last decade, with limited research prior to 2000 (d'Astous \& Landreville, 2003). Much of the focus of POS research has been on the use of monetary strategies, such as price discounts and coupons (Hardesty \& Bearden, 2003; Laroche et al., 2001; Palazón \& Delgado, 2009; Phillips et al., 2015). However, concerns regarding the negative impacts of these approaches, including increased price sensitivity and dilution of brand equity (Chandon et al., 2000; Montaner et al., 2011; Mela et al., 1997), have led to a greater focus on non-monetary POS strategies. Investigations into the use of non-monetary POS strategies have included: the impact of in-store displays on trial and re-purchase (Ndubisi \& Mooi, 2005; Jannson et al., 2002); the use of in-store sampling (Heiman et al., 2001; Bawa \& Shoemaker, 2004; Heilman et al., 2011; Nordfält \& Lange, 2013); the impact of in-store events (Sands et al., 2009); the use of gift promotions (Montaner et al., 2011); and the use of in-store promotional videos (Russell, 2008).

Several gaps remain in the POS literature. While research has typically evaluated the impact of single POS tactics, few investigations have considered the overall design and implementation of POS strategies. This is particularly the case with regard to: (i) which POS items are more effective; (ii) how many items are needed; and (iii) how retailers contribute to the overall design and implementation of the strategy. Within the context of food, much of the existing research has been conducted in supermarkets (Gittelsohn et al., 2009) or convenience stores (Russell, 2008), with no research evident in the specialty store context. Moreover, most POS research focusses on consumer attitudes and behaviours with little research considering the retailer's perspective (Fam et al., 2011).

This study addresses the research question of 'How can non-monetary POS strategies be implemented to increase consumption frequency of Australian oysters?'. Specifically, we explore the implementation of a 
holistic non-monetary POS strategy in speciality seafood stores and attempt to identify which strategies are most effective and to determine the impact that management and staff have on results of the POS campaign.

\section{Theoretical framework}

Traditionally, POS promotions have focussed on short term goals, including maximising sales through stimulating impulse buying, purchasing a larger quantity than planned, or reducing the time between purchases (Laroche et al., 2001), with these goals achieved predominantly through monetary-based POS tactics. Consequently, POS studies have focussed on the impact of monetary-based tactics on immediate sales. Monetary-based POS tactics are considered to provide primarily utilitarian benefits, such as cost savings and increased convenience, resulting from reduced customer search time and effort (Banerjee, 2009).However, monetary based incentives are less likely to be persuasive in the specialty store setting, where consumers are more highly involved and shopping motivations are more aligned with acquiring specific product attributes and a willingness to pay a premium for quality (Moore, 2010).

In addition to increasing sales, an emerging use of POS is one that increases awareness and knowledge through non-monetary tactics as a pathway to longer term behavioural change (Glanz \& Yaroch, 2004). Trials in supermarkets have indicated that non-monetary POS can improve consumer knowledge, purchase, and consumption frequency of foods (Gittelsohn et al., 2009). Non-monetary POS tactics also deliver hedonistic benefits such as improved self-expression, added stimulation and variety, and entertainment value (PalazónVidal \& Delgado-Ballester, 2005; Chandon et al., 2000). In addition, non-monetary approaches are deemed to facilitate customer franchise and brand building, as they focus on issues other than price (Palazón-Vidal \& Delgado-Ballester, 2005).

Non-monetary promotional tactics that focus on behavioural change are appproproate to use with products such as oysters which are usually associated with hedonistic motivations and special occasions (Danenburg \& Mueller, 2011). As a consequence, the goal of any POS strategy aimed at a prolonged increased demand for oysters would be twofold: first interrupt current purchase behaviour and second, improve knowledge and awareness to positively influence attitudes and behaviours, thus stimulating more frequent purchase and longer term behavioural change. 
This leads to our first proposition that: Non-monetary POS strategies will have a positive impact on both immediate sales and longer term likelihood to purchase.

Non-monetary POS strategies encompass a wide of tactics including signage, brochures, displays, and in-store sampling to inform consumers and highlight different product features and attributes (Palazón-Vidal \& DelgadoBallester, 2005). These approaches impact consumer behaviour with Nikolova and Inman (2015) finding that the introduction of an easy to process nutrition scoring system at POS led to healthier food choices, as consumers became more sensitive to the promotion and less sensitive to price. Likewise, in a controlled experiment across two supermarkets, Ogawa et al. (2011) found that health-related information for vegetables led to an $18.7 \%$ increase in sales.

Limited research has been conducted comparing various non-monetary POS tactics and their impact on consumer behaviour. A study on the retailing of health foods, in which print materials were implemented at POS in both supermarkets and corner stores, found that posters and signage were more effective than shelf labels (Gittelsohn et al., 2009). In relation to seafood, a study conducted in the Netherlands on how seafood could be made more mentally accessible to consumers revealed that easy access to inspiring recipes encouraged people to prepare high-quality dishes at home (Blank, 2012). POS is largely a visual medium, but given the competition for consumer attention in stores, a single POS tactic may not be noticed. However, previous studies have neither considered the number or combination of POS tactics which are optimal to meet the goals of both awareness and knowledge. The research on POS for food has not compared the impact of 'fixed' POS materials, such as posters and displays, with information-rich collateral, such as information brochures and recipe cards which consumers can take away and peruse at their leisure.

POS collateral increasingly appeals to more than just the visual sense, with the use of aural POS strategies (instore radio or television) and kinaesthetic approaches (touch screen technology) becoming more prevalent in addition to hands-on demonstrations and product sampling/tasting. Studies in the popular press strongly support in-store sampling as one of the most effective POS techniques in generating trial and purchase (Marketing Week, 2007, Brandweek, 1995). This is confirmed by academic research which reports that sampling can be a powerful POS tool on immediate consumers, although its long term effectiveness is unknown (Heiman et al., 2001; Lammers, 1991; Brandweek, 1995; Heilman et al., 2011; Nordfält \& Lange, 2013). In-store sampling has been hypothesised to have three potential impacts on sales: acceleration, cannibalisation, and expansion (Bawa \& Shoemaker, 2004). Our study predicts an 'acceleration effect', which occurs when existing consumers who 
purchase oysters occasionally may purchase oysters in addition to their planned seafood species after receiving a free sample. A significant 'expansion effect', occurring where there is an increase in eventual buyers, but would not have tried the product without the availability of a free sample, is deemed as less likely, as oysters are already widely consumed, with research indicating those who do not already eat oysters are unlikely to try them (Danenburg \& Mueller, 2011). A ‘cannibalisation effect’, where consumers who purchase oysters occasionally may purchase oysters instead of other seafood species is not considered likely, as oysters are typically purchased as a supplement to the main meal.

The effectiveness of in-store sampling has been shown to be dependent on the extent to which the retailer supports the sampling with other POS collateral (Nordfält \& Lange, 2013). However, there is no indication of the amount, forms, or combinations of collateral necessary for a POS strategy to be effective. Moreover, the efficacy with which the sales person or demonstrator undertaking the sampling conveys compelling arguments, exhibits good selling skills and product knowledge is critical for success (Nordfält \& Lange, 2013).

Our second proposition is: Individual non-monetary POS strategies will differ in effectiveness, with in-store sampling predicted to have the greatest impact on sales.

Producers/manufacturers and retailers play different roles in POS and may have differing objectives. The producer is likely to have in-depth product knowledge and be focussed on specific brands, while the retailer is more concerned with performance of the overall product category and controlling in-store placements and decisions. While the producer or manufacturer designs and develops the in-store POS strategy and associated collateral, the retailer is primarily responsible for implementation. Implementation decisions, such as the correct placement of POS collateral, have been found to be critical to the overall success of the POS strategy (Gittelsohn et al., 2009). Both frontline employees and management play a role in the success of POS promotions (Marketing Week, 2007), but research estimates that an average of 20\% (and as much as 50\%) of POS spend is wasted through incorrect implementation (Path to Purchase Institute, 2012). If retail staff have an understanding of how POS affects sales, they can reinforce the POS campaign message (Marketing Week, 2007). However, there is no guarantee that retail staff will want to become involved in POS activities without instruction and incentives. To increase the likelihood of success of a POS campaign, employees and management must accept responsibility for the execution of the campaign (Path to Purchase Institute, 2012). Not only will educating staff about POS purpose and tactics lead to an increase in sales, it will also enhance the customer service experience (Marketing Week, 2007). 
The impact of staff is particularly important in the speciality store setting as Moore (2010) argues that specialty stores provide an important educational service with shoppers benefiting from staff expertise and advice as the point of purchase. However, unless staff are armed with appropriate training and materials, they are unable to fulfil this educational role.

This leads to our third and final proposition that: Management and staff commitment will impact the success of non-monetary POS strategies.

In summary, our study explores how POS can be used to achieve behavioural change and encourage consumers to more frequently purchase an underutilised food product such as oysters. The study addresses the gaps in the literature by exploring: (i) the impact of a non-monetary POS strategy on sales and likelihood to purchase; (ii) the effectiveness of individual POS collateral; and (iii) the role of management and staff in the effective implementation of a POS campaign.

\section{Method}

Based on extensive research into oyster consumption in Australia, which identified barriers to consumption and consumer attitudes and preferences towards oysters, a field trial was designed and implemented by members of the Australian Seafood Cooperative Research Centre and the Australian oyster industry. Specialty seafood stores were selected for the trial, as they are the preferred place of purchase of Australian consumers for at-home consumption of oysters (Kow et al., 2008). The trial was conducted in eight specialty seafood stores over a four month period. All eight stores were members of the same corporate group, with seven corporate-owned stores and one franchise store. This corporate group was chosen as it was reputable and well known to consumers, provided a suitable number of stores for the trial, and allowed for greater planned control and ease of implementation through central management. Two of the eight stores were designated as control stores with no changes in POS, three stores received a variety of POS collateral, while the final three stores received the POS collateral and six hours of in-store sampling of oysters per week (three hours on two separate days) for the period of the trial (16 weeks).

The POS materials were developed based on the findings of consumer research and were designed with the dual purposes of attracting attention and stimulating immediate purchase, in addition to providing information to increase consumer knowledge and confidence. Four items of collateral were developed: 
- Posters depicting consumers eating oysters in a casual social setting. The posters were designed to both attract attention and convey the idea of oyster consumption being suitable for any social or everyday occasion (rather than being limited to special occasions);

- Stickers for use on packaging to provide information about species, taste, storage, and provenance. Two stickers were developed, one for each of the major species of oysters available in Australia: Pacific Oysters and Sydney Rock Oysters. Each sticker nominated the species, described the flavour profile of the species, highlighted how best to store oysters, and indicated provenance via a map of Australia indicating the growing regions for each species;

- Display units (for in-store cabinetry) were designed to attract attention and convey information. The front panels of the display units included similar information to the stickers, that is, they clearly identified species and provenance via a map;

- A brochure containing information about species, storage, and provenance; as well as recipes.

The POS collateral was designed to gain attention in-store (displays and posters) as well as to provide more detailed information for the customer to consider at home (brochures and stickers). The in-store sampling was undertaken by a professional fieldwork company following a schedule based on input from store management to cover peak trading times and days. Staff education and training materials to support the POS materials were developed and distributed to trial stores.

A multi-method approach for gathering data to address the three research propositions was adopted to allow triangulation from several sources including sales data, consumer surveys, store management and staff surveys, as well as observations made by the research team and in-store demonstrators. The six approaches used to evaluate the propositions are summarised in Table 1.

Our first proposition was that non-monetary POS strategies will have a positive impact on both immediate sales and likelihood to purchase. As previous studies had noted the shortcomings of relying solely on sales data for assessing POS strategy (Glanz \& Yaroch, 2004), especially in the context of small business who are often unwilling to disclose exact sales figures (Dhanaraj \& Beamish, 2003), data to address proposition one was gathered through both sales data and subjective assessments of impact on sales provided by management. In addition, consumers were surveyed about their likelihood to purchase after exposure to the strategy and the in store demonstrators recorded sales data during the sampling sessions. Before commencement of the trial, corporate management agreed to provide pre-, post-, and during sales data for all stores, as well as the 
equivalent data for the same period in the previous year. This data would allow the measurement of the impact of the POS campaign and the demonstrations to be identified, while acknowledging that other extraneous factors may also have impacted sales over this period. Individual store managers were surveyed at the end of the trial period to gain their perceptions of the impact of the POS and sampling on sales. Further, customers likelihood of purchase after exposure to the POS was also gathered through an in store survey and in store demonstrators recorded sales during their sampling sessions as well as data regarding the number of consumers who converted from sampling to purchase.

Our second proposition that individual non-monetary POS strategies will differ in effectiveness, with in-store sampling predicted to have the greatest impact on sales, was explored through in store surveys of consumers and management and staff, as well as the reports of the in store demonstrators. In-store consumer surveys were undertaken by a member of the research team midway through the trial. Consumer surveys were administered during a two-hour period in each store. Each consumer was questioned face-to-face for a maximum of five minutes and asked to evaluate each aspect of the POS campaign with regard to awareness, impact, and the likelihood of purchase. Surveys of store managers and their staff were undertaken concurrent with the consumer surveys and sought their evaluation of the effectiveness and impact of the various components of the POS campaign. In-store demonstrators collected summary evaluations weekly including the number, gender, and approximate age of consumers sampling the oysters as well as any comments from consumers.

Our third and final proposition that management and staff commitment will impact the success of non-monetary POS strategies was addressed through manager and staff surveys, sand store visit observations. This proposition was also used to explore differences in the results of our first and second propositions.

Table 1 - Summary of Evaluation Methods

\begin{tabular}{|c|c|c|c|}
\hline $\begin{array}{l}\text { Evaluation } \\
\text { Method }\end{array}$ & $\begin{array}{l}\text { Administered/ } \\
\text { sourced }\end{array}$ & Timing & Objective \\
\hline Sales (data) & $\begin{array}{l}\text { Corporate sales } \\
\text { manager }\end{array}$ & $\begin{array}{l}\text { Sales data supplied for } 4 \text { weeks } \\
\text { pre- and post- the } 16 \text {-week trial. } \\
\text { Sales data also supplied for same } \\
\text { period in the previous year }\end{array}$ & $\begin{array}{l}\text { Compare sales between } \\
\text { interventions. } \\
\text { Allow quantification of overall } \\
\text { impact of POS campaign. }\end{array}$ \\
\hline $\begin{array}{l}\text { Sales (perceived } \\
\text { change) }\end{array}$ & Store Managers & 4 weeks after completion of trial & Triangulate with sales data \\
\hline $\begin{array}{c}\text { Store visit } \\
\text { observations }\end{array}$ & Research team & $\begin{array}{l}4 \text { times for each intervention } \\
\text { store during trial }\end{array}$ & $\begin{array}{l}\text { Fidelity, i.e. check that the POS } \\
\text { materials were used correctly }\end{array}$ \\
\hline $\begin{array}{l}\text { In-store consumer } \\
\text { surveys }\end{array}$ & Research team & One mid-trial visit & $\begin{array}{c}\text { Investigate consumer attitudes } \\
\text { and behaviours of the POS } \\
\text { campaign }\end{array}$ \\
\hline $\begin{array}{c}\text { In-store } \\
\text { management and }\end{array}$ & Research team & One mid-trial visit & $\begin{array}{l}\text { Investigate management } \\
\text { perceptions and attitudes of the }\end{array}$ \\
\hline
\end{tabular}




\begin{tabular}{|c|c|c|c|}
\hline staff survey & Field work & Weekly reports & POS campaign \\
\hline $\begin{array}{c}\text { In-store } \\
\text { demonstrators } \\
\text { evaluations and } \\
\text { reports }\end{array}$ & $\begin{array}{c}\text { company and } \\
\text { demonstrators }\end{array}$ & $\begin{array}{c}\text { Quantification of results as well } \\
\text { as observation and qualitative } \\
\text { summary of consumer feedback }\end{array}$ \\
\hline
\end{tabular}

To improve reliability and validity of results, a member of the research team visited each of the six stores implementing the POS a minimum of four times during the trial to ensure that POS materials were being used correctly and to address any concerns and queries from management and staff.

This study was subject to external influences outside the control of the research team. For example, before the trial commenced, one of the eight stores (designated as POS only) closed for several months due to renovations in the shopping centre in which it was located.

\section{Results}

Before reporting the analysis and results for each of three research propositions the results of the fidelity checks through instore visits are outlined to provide context for interpreting results.

Store visit observation. Each store was visited by the same member of the research team on a minimum of four occasions throughout the trial. A key objective of these visits was to improve validity and reliability by checking fidelity that is that the POS materials were being displayed and used as designed. Table 2 summarises the main observations within each store for each item of POS collateral over the trial period.

Table 2 - Summary of In-store Observations

\begin{tabular}{|c|c|c|c|c|c|}
\hline & $\begin{array}{l}\text { POS \& Sampling } \\
\text { (Franchise store) }\end{array}$ & $\begin{array}{c}\text { POS \& } \\
\text { Sampling } \\
\text { (Corporate } \\
\text { Store 1) }\end{array}$ & $\begin{array}{c}\text { POS \& } \\
\text { Sampling } \\
\text { (Corporate } \\
\text { Store 2) }\end{array}$ & $\begin{array}{l}\text { POS only } \\
\text { (Corporate } \\
\text { Store 1) }\end{array}$ & $\begin{array}{l}\text { POS only } \\
\text { (Corporate } \\
\text { Store 2) }\end{array}$ \\
\hline $\begin{array}{l}\text { Oyster } \\
\text { range } \\
\text { carried }\end{array}$ & $\begin{array}{c}\text { Increased range } \\
\text { from } 2 \text { to } 3 \\
\text { varieties }\end{array}$ & $\begin{array}{l}\text { Consistently } 2 \\
\text { varieties, } \\
\text { occasionally } 3\end{array}$ & $\begin{array}{c}\text { Consistently } 2 \\
\text { varieties, } \\
\text { occasionally } 1\end{array}$ & $\begin{array}{l}\text { Consistently } 2 \\
\text { varieties, } \\
\text { occasionally } 1\end{array}$ & $\begin{array}{c}\text { Consistently } 2 \\
\text { varieties, } \\
\text { occasionally } 1\end{array}$ \\
\hline Brochures & $\begin{array}{l}\text { On display and in } \\
\text { bags }\end{array}$ & On display & $\begin{array}{l}\text { Only on display } \\
\text { during in-store } \\
\text { sampling }\end{array}$ & On display & On display \\
\hline Posters & On display & Not permitted & On display & Insufficient room & On display \\
\hline Stickers & Yes & $\begin{array}{l}\text { Only when not } \\
\text { busy }\end{array}$ & Not used & $\begin{array}{l}\text { Only when not } \\
\text { busy }\end{array}$ & Not used \\
\hline
\end{tabular}




\begin{tabular}{|c|c|c|c|c|c|c|}
\hline $\begin{array}{c}\text { Display } \\
\text { trays }\end{array}$ & Yes & $\begin{array}{c}\text { No (store } \\
\text { manager did not } \\
\text { like them) }\end{array}$ & Yes & Yes \\
\hline Other & $\begin{array}{c}\text { Oysters moved to } \\
\text { centre of display } \\
\text { cabinet }\end{array}$ & $\begin{array}{c}\text { Oysters moved to } \\
\text { centre of display } \\
\text { cabinet }\end{array}$ & N/A \\
$\begin{array}{c}\text { Additional posters } \\
\text { throughout } \\
\text { shopping centre } \\
\text { advertising } \\
\text { sampling times }\end{array}$ & & & N/A \\
In-store shucking & & & \\
\hline
\end{tabular}

The use and positioning of POS materials varied between all stores and were determined by store design, layout and location, as well as management and staff preferences. As shown in Table 2, one store did not have the posters on display as they were not permitted by shopping centre management, while another store was unable to display the posters due to limited wall space. Management at one store only had the brochures on display when the demonstrator was in-store. The manager of this store also disliked the display trays provided and chose not to use them. In all cases where materials were not being used as intended, a subsequent request was made to follow the plan but store management (who controlled these operational issues) declined the request - citing that staff were too busy or that they simply did not like the POS material. While this non-compliance was not anticipated, it does support the practitioner literature indicating that limited or incorrect implementation can negatively impact the success of a POS strategy (Path to Purchase Institute, 2012).

Consistent with the sales performance data, the franchise store was observed to implement all POS materials as planned. The franchise store also implemented additional support activities, such as displaying posters throughout the centre, promoting the days and times when in-store sampling was occurring, and placing brochures in the shopping bag with customer purchases. This store also moved the position of oysters from a back corner to a centre-front position within the store very early in the trial and increased the range of oyster provenances available. The store manager also began shucking oysters in-store.

These observations highlighted two issues, first that management and staff commitment played a key role in successful implementation of the POS strategy (as per proposition 3) and secondly that physical issues around store layout and design and regulations impacting some stores made items of collateral like posters unworkable. 


\section{Proposition 1. Non-monetary POS strategies will have a positive impact on both immediate sales and likelihood to purchase.}

Data to address this proposition was gathered from four sources: sales data, manager's assessment of sales impact, demonstrators reports and consumer’s likelihood of purchase.

Sales data. When the trial period ended and sales data was requested from corporate management, several issues emerged. Sales data was not centrally available, as had been initially indicated, but had to be obtained from each individual store (and store manager). Of the seven stores, one store (a control store) could not provide any data due to a computer failure, six stores had missing sales data ranging from one week to one month, one store did not keep data outside of the current financial year, and each store used different product codes, with some product codes not reflecting the quantity of oysters. Consequently, there were concerns about the validity of sales data provided by six of the seven trial stores. The exception was the franchise store, where the data was complete and appeared accurate. The store observations reported previously confirmed the high management commitment at this franchise store. This store used both the POS material and in-store sampling, with sales results indicating a doubling of oysters' sales across the POS campaign as compared to the same period the previous year. These experiences confirm previous research about the reliability and use of sales data (Gittelsohn et al., 2009) and support the need to triangulate sales data from other sources.

Store managers' subjective assessment of sales. Store managers were telephoned on completion of the trial and asked for their opinions of the impact of the POS and in-store sampling on sales. With the exception of the one store that used the POS materials but did not undertake in-store sampling, managers reported a positive impact ranging from an estimated 15 to 50\% increase in oyster sales compared to the same period in the previous year, with the retail operations manager (who oversees all stores) suggesting an average $20 \%$ increase in oyster sales during the trial period.

Demonstrator's reports. Demonstrators were required to report weekly on a series of questions after each sampling session and to record unprompted consumer feedback. When demonstrators were in-store, oyster sales increased significantly. Approximately one in three people who sampled the oysters went on to purchase, although the level of increase varied by store, time, and day of demonstration period. Demonstrators reported that over $80 \%$ of consumers were unaware of different oyster provenances and types. As demonstrators were positioned at store entrances, sampling encouraged consumers to enter stores, and demonstrators reported that of 
the consumers who had sampled oysters from the demonstrator on a previous occasion, $44 \%$ had returned to purchase oysters again within the trial period. Consumer comments included: 'I'm buying oysters so much more than normal because of the sampling' and 'I'm so excited to try the oysters'. As previously noted, the variability in the performance of demonstrators was evident, with one demonstrator clearly outperforming the other two in terms of product knowledge and selling skills.

Finally, consumers indicated a positive likelihood of purchase after exposure to the POS collateral.

Proposition 2. Individual non-monetary POS strategies will differ in effectiveness, with in-store sampling predicted to have the greatest impact on sales.

Data to address this proposition was gathered through in store surveys of both consumers and managers and staff as reported next.

In-store consumer surveys. Sixty-two consumer interviews were undertaken in four of the five trial stores over a two-day period. As indicated in Table 2, each store differed in how, when, and if they used the POS materials. The number of respondents by store varied from a low of seven to a high of 21 . Of the 62 consumers surveyed, 23 (37\%) noticed the POS collateral, while all respondents in stores with sampling $(\mathrm{n}=42)$ noticed and took advantage of the oyster tasting opportunities. As shown in Table 3, of those who noticed the POS, just less than half of them (11 people) noticed only one item and only one person noticed all four items; the display trays and brochures were the most frequently noticed POS items.

Table 3 - POS Collateral Noticed by Respondents

\begin{tabular}{|c|c|c|c|c|c|}
\hline & $\begin{array}{c}\text { 1 item } \\
\text { noticed }\end{array}$ & $\begin{array}{c}\text { 2 items } \\
\text { noticed }\end{array}$ & $\begin{array}{c}\text { 3 items } \\
\text { noticed }\end{array}$ & $\begin{array}{c}\text { 4 items } \\
\text { noticed }\end{array}$ & Total \\
\hline Display Trays & 2 & 3 & 7 & 1 & $\mathbf{1 3}$ \\
\hline Brochures & 5 & 2 & 5 & 1 & $\mathbf{1 3}$ \\
\hline Stickers & & 2 & 7 & 1 & $\mathbf{1 0}$ \\
\hline Poster & 4 & 1 & 2 & 1 & $\mathbf{8}$ \\
\hline Total respondents & $\mathbf{1 1}$ & $\mathbf{4}$ & $\mathbf{7}$ & $\mathbf{1}$ & \\
\hline
\end{tabular}

Respondents were asked to rate the POS materials on a ten-point scale ( 1 = poor to $10=$ excellent), and all materials were positively rated (>6.8). Display trays had the highest average score (8.32), followed closely by the brochure (8.13). This positive rating of POS materials was supported by a positive likelihood to influence purchase (3.59 on a five-point scale, where 5 = highly likely). At the three stores implementing in-store 
sampling, this strategy significantly out-rated all other POS activities in terms of both consumer perceptions $($ mean $=9.93)$ and impact on likelihood of purchase $($ mean $=4.79)$.

Of the respondents surveyed, approximately 50\% purchased oysters only once or twice a year, with two-thirds reporting that oysters are an impulse purchase. Predominantly, oysters are purchased in addition to another seafood (68\%), indicating the purchase of oysters is not cannibalising the purchase of other seafood for most consumers. These three results were consistent across all five stores.

Manager and staff surveys. Face to face interviews were undertaken across the five trial stores with six store managers (as one store had two managers) and eight staff members. All managers and staff reported the POS materials had a positive impact on consumers, but importantly, 13 of the 14 reported a significant improvement in their own knowledge and attitude towards oysters, with comments from managers such as: 'My staff can now connect with customers about oysters', and 'All of my staff are now learning how to shuck oysters' and from staff: 'I never knew there were so many oyster flavours'. This shows that educating store staff may be as important as the POS strategies themselves and supports Moore (2010) who highlights the educational role expected of staff in a specialty store setting.

When rating the POS materials (on the same 10-point scale as consumers), all materials were rated positively (>7.0). However, all four pieces of collateral attracted diverse ratings from staff. For example, one manager disliked the display trays, two staff disliked using the stickers (due to time and inconvenience of applying them when busy), two did not like the brochures, and one disliked the posters.

In terms of the in-store sampling, one manager rated the sampling very highly (10 out of 10), with nine other managers and staff giving positive but lower ratings (7 or 8 out of 10). Reasons given for lower ratings reflected the skills and ability of the individual store demonstrators, with one demonstrator clearly outperforming the other two. Managers and staff highlighted that the quality and impact of the demonstrations was highly dependent on the quality of the demonstrator, in terms of selling skills and product knowledge, supporting Nordfalt and Lange's (2013) finding that the efficacy of the demonstrators is critical to success. Despite the variability in performance of the demonstrators, staff reported a positive impact from the demonstrations including an increase in sales and numbers of new customers entering the store after engagement with the demonstrators at the store front. 
On the negative side, managers noted the lack of flexibility of outsourcing the in-store sampling. While store managers had input in deciding the days and times that were considered most suitable, this had to be arranged in advance and reduced the flexibility to meet immediate conditions. For example, when store traffic was lower than normal due to weather conditions, the in-store demonstrations still went ahead as scheduled. Managers indicated a preference for using their own staff to conduct sampling to allow greater flexibility in timing of sampling sessions, and this in turn may lead to greater management commitment. This finding supports the contention that the likelihood of success of a POS campaign success is increased when management accept responsibility for the execution of the campaign (Path to Purchase Institute, 2012).

\section{Proposition 3. Management and staff commitment will impact the success of non-monetary POS} strategies.

Data to explore the third proposition was gathered from the store observation visits and the manager and staff surveys as reported previously. Consistent with previous findings (Marketing Week, 2007, Path to Purchase Institute, 2012), the impact of managers and staff on the success of the POS campaign was significant.

The commitment of managers varied, as reflected by the implementation of the collateral, with the franchise store manager showing the highest commitment as evidenced by not only implementing all collateral as prescribed but also taking further steps to support the POS strategies. This store reported the highest sales increase (83\%) during the period of the trial and also reported new customers entering the store. Additional support was evidenced during the manager and staff surveys where reported benefits included staff being more motivated as they learned about the product, with a consequential reduction in the frequency of staff asking store managers about oysters. Staff were also more confident and better informed when talking to customers.

\section{Discussion}

Despite the issues around fidelity outlined in the results, the use of in-store sampling when supported by POS materials, committed management and staff, and skilled demonstrators resulted in a significant increase in sales volume without any reduction in price or cannibalisation of other products. While still positive, the results were less clear on the impact of POS alone, which were confounded by non-compliance issues with the 
implementation of the plan and lower levels of management and staff commitment. While management and staff commitment had been proposed to impact success (Marketing Week, 2007), the levels of non-compliance and low commitment we experienced had not been anticipated at the commencement of the trial. However, reflection throughout the trial, especially when considering the compliance and high levels of commitment of the franchise store owner, suggested that as non-owners, managers may be less motivated by achieving greater sales.

Consistent with previous research, in-store sampling was clearly the most effective POS strategy (Heilman et al., 2011). The importance of the efficacy of the in-store demonstrator (Norfalt \& Lange, 2013) was also evident, with management feedback, in-store observation, and sales data supporting the variability between the store demonstrators - with one demonstrator significantly outperforming the other two. The demonstrators were supplied and supervised by a firm specialising in providing such field staff, with the research team providing additional training and information specific to oysters to these staff (who had not previously worked with oysters). Individual store managers had no input into the selection of the demonstrators who were allocated to their stores by the field work organisation. Our results suggest that in-store sampling may be even more successful if individual store managers have more control over selection of demonstrators, as well as greater flexibility in scheduling days and times for sampling. Giving control to store management may also positively impact management commitment to the POS strategy.

In terms of the four items of POS materials, while all received positive feedback, the display trays and the brochures promoted higher awareness and knowledge than the posters and stickers. It should be noted that none of the four items were used consistently across the five stores for a variety of reasons: store design, management preferences, and regulations around store location. These are variable factors to consider when assessing which materials worked most effectively within in each store. This highlights the practical benefits of having a variety of POS materials to accommodate the range of usage contexts and to appeal to different target markets. While previous research highlighted the position of sampling as one of the most effective POS techniques (Heiman et al. 2011; Nordfalt \& Lange 2013), no previous research was identified exploring the comparative effectiveness of other forms of non-monetary POS, thus these findings contribute to knowledge in this area.

Evidence and observations throughout the trial showed that active management commitment was a key factor behind the strong performance of the franchise store. All other stores were run by non-owner managers with less apparent commitment to the project. Differences in commitment were also noted during the consumer and staff surveys carried out during the trial period. Two stores were highly supportive and committed to the trial: the 
franchise store and the store with the outstanding demonstrator (Corporate Store 1). The other three managers showed significantly less commitment to the POS campaign and demonstrated lower compliance levels.

\section{Conclusions and Implications}

This study evaluated the implementation of a POS strategy in the context of an underutilised seafood product, oysters, in the setting of speciality seafood stores. Data were gathered from retailers and consumers. Our study reveals that non-monetary POS materials can be used to change behaviour associated with less familiar products through opportunities for trial (in-store sampling) and by increasing the product knowledge of both consumers and store staff.

Outcomes from the study included better understanding of : (i) the key role of store managers and staff in ensuring the successful implementation and outcomes of a POS strategy; and (ii) the specialty store context, as store locations and layouts may necessitate different POS collateral. This study also makes a contribution to theory by exploring issues around the effectiveness of individual components of a non-monetary POS strategy that had not previously been addressed.

Practically, the study has several implications and supports the positive value of in-store sampling, the importance of up-skilling staff in terms of product information and knowledge, and the importance of management commitment to the POS campaign. The study also highlights the need to produce a variety of welldesigned and consumer-focussed POS materials to accommodate the range of physical layouts and locations of speciality stores. Specifically, in relation to in-store sampling, the key role of the demonstrator was highlighted. A good demonstrator needs a combination of personal selling skills and product knowledge to be successful. Smaller speciality stores would also benefit from the flexibility of not being locked into a fixed schedule of outsourced demonstrations by third parties.

This study provides important insights into key success factors when designing and implementing a nonmonetary POS strategy. We considered one underutilised food product, oysters, in the setting of speciality retail stores; where the goal was to increase purchase frequency and change purchase behaviour over a 16-week period. Future research will involve following up the survey to study longer-term changes in purchase behaviour. Finally, the common issues associated with attaining fidelity in real world research, and subsequent impacts on data reliability, need to be considered when designing future field experiments. 


\section{List of References}

Banerjee, S. (2009). Effect of product category on promotional choice: comparative study of discounts and freebies. Management Research News, 32 (2), 120-131, doi:

http://dx.doi.org/10.1108/01409170910927587

Bawa, K., \& Shoemaker, R. (2004). The effects of free sample promotions on incremental brand sales. Marketing Science, 23 (3), 345-363, doi: http://dx.doi.org/10.1287/mksc.1030.0052

Belch, G. E. \& Belch, M. A. (2007). Advertising and Promotion: An Integrated Marketing Communications Perspective, 7th edn, McGraw Hill, New York.

Birch, D., \& Lawley, M. A. (2014). The role of habit, childhood consumption, familiarity, and attitudes across seafood consumption segments in Australia. Journal of Food Products Marketing, 20 (1), 98-113, doi: http://dx.doi.org/10.1080/10454446.2012.732548

Blank, C. (2012). Seafood Source, Seafood News Foodservice \& Retail [news bulletin]. URL http://www.seafoodsource.com/news/foodservice-retail/road-to-brussels-anova-bridges-information-gap

Brandweek (1995). Free for all; there's a lot of good ways to get the word - and your product - out there: A new look at the power of product sampling. Brandweek, 36 (11), 5-9.

Chandon, P., Wansink, B., \& Laurent, G. (2000). A benefit congruency framework of sales promotion effectiveness. Journal of Marketing, 64 (4), 65-81, doi: http://dx.doi.org/10.1509/jmkg.64.4.65.18071 d'Astous, A., \& Landreville, V. (2003). An experimental investigation of factors affecting consumers' perceptions of sales promotions. European Journal of Marketing, 37 (11/12), 1746-1761, doi: http://dx.doi.org/10.1108/03090560310495447

Danenberg, N., \& Mueller, S. (2011). 'Omnibus Consumer Research Findings - Wave 2', Omnibus Study, Ehrenberg-Bass Institute for Marketing Science, University of South Australia, Australian Seafood CRC, Adelaide. URL

http://www.seafoodcrc.com/components/com_virtuemart/attachments/2011\%20Omnibus\%20Wave\%202\%20R eport.pdf

Dhanaraj, C., \& Beamish, P. W. (2003). A Resource-Based Approach to the Study of Export Performance. Journal of Small Business Management, 41(3), pp242-261, http://dx.doi.org/10.1111/1540-627X.00080 
Fam, K-S., Merrilees, B., Richard, J. E., Jozsa, L., Li, Y., \& Krisjanous, J. (2011). In-store marketing: a strategic perspective. Asia Pacific Journal of Marketing and Logistics, 23 (2), 165-176, doi:

http://dx.doi.org/10.1108/13555851111120470

Gittelsohn, J., Suratkar, S., Song, H-J., Sacher, S., Rajan, R., Rasooly, I. R., Bednarek, E., Sharma, S., \& Anliker, J. A. (2009). Process evaluation of Baltimore health stores: a pilot intervention program with supermarkets and corner stores in Baltimore City. Health Promotion Practice, 11 (5), 723-732, doi: http://dx.doi.org/10.1177/1524839908329118

Glanz, M. P. H., \& Yaroch, A. L. (2004). Strategies for increasing fruit and vegetable intake in grocery stores and communities: policy, pricing, and environmental change. Preventative Medicine, 39 (2), 75-80, doi: http://dx.doi.org/10.1016/j.ypmed.2004.01.004

Hardesty, D. M., \& Bearden, W. O. (2003). Consumer evaluations of different promotion types and price presentations: the moderating role of promotional benefit level. Journal of Retailing, 79 (1), 17-25, doi: http://dx.doi.org/10.1016/S0022-4359(03)00004-6

Heilman, C., Lakishyk, K., \& Radas, S. (2011). An empirical investigation of in-store sampling promotions. British Food Journal, 113 (10), 1252-1266, doi: http://dx.doi.org/10.1108/00070701111177674

Heiman, A., McWilliams, B., Shen, Z., \& Zilberman, D. (2001). Learning and forgetting: modeling optimal product sampling over time. Management Science, 47 (4), 532-546, doi:

http://dx.doi.org/10.1287/mnsc.47.4.532.9832

Honkanen, P., Olsen, S. V., \& Verplanken, B. (2005). Intention to consume seafood - the importance of habit. Appetite, 45 (2), 161-168, doi: http://dx.doi.org/10.1016/j.appet.2005.04.005

Jansson, C., Bointon, B., \& Marlow, N. (2002). Determinants of consumers’ aesthetic responses to Point-ofPurchase materials. International Journal of Consumer Studies, 26 (2), 145-153, doi: http://dx.doi.org/10.1046/j.1470-6431.2002.00218.x

Kow, F., Yu, L., FitzGerald, D., \& Grewal, D. (2008). Understanding the factors related to the consumers' choices of oysters in Australia: an empirical study. Journal of Foodservice, 19 (4), 245-253, doi: http://dx.doi.org/10.1111/j.1748-0159.2008.00112.x 
Lammers, H. B. (1991). The effect of free samples on immediate consumer purchase. Journal of Consumer Marketing, 8 (2), 31-37, doi: http://dx.doi.org/10.1108/07363769110034992

Laroche, M., Pons, F., Zgolli, N., \& Kim, C. (2001). Consumers use of price promotions: a model and its potential moderators. Journal of Retailing and Consumer Services, 8 (5), 251-260, doi: http://dx.doi.org/10.1016/S0969-6989(00)00031-X

Liu, Y., Kow, F., Grewai, D., \& Fitzgerald, D. (2006). Consumer purchase behaviour for oysters: an empirical study in some state capital cities of Australia. International Journal of Consumer Studies, 30 (1), 85-94, doi: http://dx.doi.org/10.1111/j.1470-6431.2005.00456.x

Marketing Week (2007). The point of your people [news bulletin]. URL http://www.marketingweek.com/2007/10/04/the-point-of-your-people/

Mela, C. F., Gupta, S., \& Lehmann, D. R. (1997). The long-term impact of promotion and advertising on consumer brand choice. Journal of Marketing Research, 34 (2), 248-261, doi: http://dx.doi.org/10.2307/3151862

Montaner, T., de Chernatony, L., \& Buil, I. (2011). Consumer response to gift promotions. Journal of Product \& Brand Management, 20 (2), 101-110, doi: http://dx.doi.org/10.1108/10610421111121099

Moore, B. (2010). The specialist retailer as a "living billboard” for the brand. Retail Digest, 30-35

Ndubisi, N. O., \& Moi, C.T. (2005). Customers behaviourial responses to sales promotion: the role of fear of losing face. Asia Pacific Journal of Marketing and Logistics, 17 (1), 32-49, doi:

http://dx.doi.org/10.1108/13555850510672278

Nikolova, H., \& Inman, J. (2015). Healthy choice: The effect of simplified point-of-sale nutritional information on consumer food choice behaviour. Journal of Marketing Research, 52 (6), 817-835, doi: http://dx.doi.org/10.1509/jmr.13.0270

Nordfält, J., \& Lange, F. (2013). In-store demonstrations as a promotion tool. Journal of Retailing and Consumer Services, 20 (1), 20-25, doi: http://dx.doi.org/10.1016/j.jretconser.2012.08.005

Ogawa, Y., Tanabe, N., Honda, A., Azuma, T., Seki, N., Suzuki, T., \& Suzuki, H. (2011). Point-of-purchase health information encourages customers to purchase vegetables: objective analysis by using a point-of-sales system. Environmental Health And Preventive Medicine, 16(4), 239-246. doi:10.1007/s12199-010-0192-8 
Palazón, M., \& Delgado, E. (2009). The moderating role of price consciousness on the effectiveness of price discounts and premium promotions. Journal of Product and Brand Management, 18 (4), 306-312, doi: http://dx.doi.org/10.1108/10610420910972837

Palazón-Vidal, M., \& Delgado-Ballester, E. (2005). Sales promotions effects on consumer-based brand equity. International Journal of Market Research, 47 (2), 179-204.

Path to Purchase Institute (2012). 'A Game Plan for P-O-P Excellence', Industry Report, Shopper Marketing, Path to Purchase Institute, Shopper Marketing Magazine, Chicago.

Phillips, M., Parsons, A. G., Wilkinson, H. J., \& Ballantine, P. W. (2015). Competing for attention with in-store promotions, Journal of Retailing and Consumer Services, 26, 141-146, doi:

http://dx.doi.org/10.1016/j.jretconser.2015.05.009

Point of Purchase Advertising International (2012). '2012 Shopper Engagement Survey', Member report, POPAI: Point of Purchase Advertising International, POPAI, Brookvale.

Russell, M. G. (2008). Point of purchase engagement boosts perception and purchase. Proceedings of the American Academy of Advertising Annual Meeting, American Academy of Advertising, San Mateo, California.

Sands, S., Oppewal, H., \& Beverland, M. (2009). The effects of in-store themed events on consumer store choice decisions. Journal of Retailing and Consumer Services, 16 (5), 386-395, doi: http://dx.doi.org/10.1016/j.jretconser.2009.05.001

Verbeke, W., \& Vackier, I. (2005). Individual determinants of fish consumption: application of the theory of planned behaviour. Appetite, 44 (1), 67-82, doi: http://dx.doi.org/10.1016/j.appet.2004.08.006 